\title{
Genitourinary infections as a risk factor for preterm prelabour rupture of membranes: a hospital based case control study
}

\author{
Aparajita Sophia D'souza ${ }^{1}$, Garima Gupta ${ }^{1}$, Divya Mahindru ${ }^{1}$, Moneet Walia ${ }^{1}$, \\ Francis Sridhar Katumalla ${ }^{2}$, Sunita Goyal ${ }^{1}$
}

${ }^{1}$ Department of Obstetrics \& Gynaecology, Christian Medical College, Ludhiana, Punjab, India
${ }^{2}$ Department of Urology, Christian Medical College, Ludhiana, Punjab, India

Received: 19 September 2015

Accepted: 29 September 2015

\section{*Correspondence:}

Dr. Aparajita Sophia D'souza,

E-mail: dsouzaaparajita@yahoo.in

Copyright: () the author(s), publisher and licensee Medip Academy. This is an open-access article distributed under the terms of the Creative Commons Attribution Non-Commercial License, which permits unrestricted non-commercial use, distribution, and reproduction in any medium, provided the original work is properly cited.

\begin{abstract}
Background: Preterm Prelabour Rupture of Membranes (PPROM) is a leading cause of maternal and neonatal morbidity and mortality. The objective of our study was to bring forward the association between genitourinary infections and PPROM in Indian scenario.

Methods: This retrospective case-control study was conducted in the Department of Obstetrics and Gynecology, in a tertiary referral teaching hospital in Punjab. A total of 150 women were evaluated for genitourinary infections and their association with PPROM. Cases group $1(n=75)$ included pregnant females with diagnosis of PPROM based on history and vaginal examination. Control group $2(n=75)$ included pregnant women admitted to labour room at 37 completed weeks of gestation or more and with no history of PPROM. The control group was matched to case group with respect to age and parity. Case to control ratio was taken as 1:1. A multivariate analysis was used to find the association between PPROM and genitourinary infections. Microsoft Excel and the Statistical Package for the Social Sciences (SPSS), Version 21 were used for data analysis. A P value of $<0.05$ was determined to be statistically significant.

Results: In our study genitourinary infections were seen in 16 women in Case Group 1 (21.3\%), compared to 7 women in Control Group (9.3\%). Genitourinary infections were associated significantly with PPROM (p 0.02) (odds ratio [OR], 2.618; 95\% Confidence interval [CI], 1.021-7.239).

Conclusions: Screening for genitourinary infections should be considered especially in high risk cases. Early recognition and prompt treatment of genitourinary infections is the key to optimize the maternal and fetal outcome in PPROM.
\end{abstract}

Keywords: PPROM, Genitourinary infections

\section{INTRODUCTION}

Preterm prelabour rupture of the membranes (PPROM) is a dreaded complication of pregnancy as it is associated with significant perinatal complications. As per the definition, PPROM is the rupture of the amniotic membranes before 37 weeks' of gestation and before the onset of labour. ${ }^{1}$ One third of the preterm births are due to PPROM and it complicates about $3 \%$ of pregnancies. ${ }^{2}$
A number of mechanisms have been proposed for PPROM. ${ }^{3-5}$ These include intrinsic membrane weakness, mechanical stress, and ascending infections to name a few. Factors that could cause weakening of the fetal membranes and have been associated with PPROM include local inflammation and infections, poor maternal nutrition, maternal smoking, and collagen deficiency syndromes. Factors associated with mechanical distention of the membranes near the internal os include 
polyhydramnios, twin pregnancy, and incompetent cervix. Trauma may be associated with PPROM through an acute increase in intra-amniotic pressure or through the production of occult contractions. Amniotic fluid has certain bacteriostatic properties that prevent infections and thereby PPROM and so oligohydramnios is also considered responsible for PPROM. In many cases, the cause of PPROM remains unknown. ${ }^{3-5}$

Evidence suggests that choriodecidual infection or inflammation is a major etiology for PPROM, especially at early gestational ages. ${ }^{6,7}$ The putative mechanism underlying infection and PPROM involves intrauterine bacterial invasion, which activates the decidua and fetal membranes to produce pro-inflammatory cytokines. Bacteria and maternal neutrophils are able to produce a number of proteolytic enzymes (e.g., collagenase, elastase, gelatinase) that can cause local weakening of the membranes. Subsequent prostaglandin production resulting from localized inflammation can lead to occult contractions and increased shearing stress at the internal cervical os. For women presenting with PPROM, not only antibiotic therapy but also screening for infections should be considered. As previously noted, PPROM may be preceded by infection, which most often ascends from the lower genital tract. ${ }^{8}$ Screening for urinary tract infections, sexually transmitted infections, bacterial vaginosis, and group B streptococcus carriage should be considered.

PPROM may cause perinatal complications like neonatal sepsis, respiratory distress syndrome, placental abruption, umbilical cord compression due to oligohydramnios and even carries a 1 to $2 \%$ risk of fetal death. ${ }^{9}$ Maternal complications like chorioamnionitis, premature delivery, and increased risk of caesarean section are also noted. ${ }^{10}$ Management of PPROM varies according to the gestational age of the fetus. Expectant management and immediate delivery are two potential options of management in patients with PPROM with its advantages and disadvantages. The objective of our study was to bring forward the association between pregnancies with PPROM and genitourinary infections in Indian scenario.

\section{METHODS}

\section{Study design}

A retrospective case-control study was conducted in the Department of Obstetrics and Gynecology, in a tertiary referral teaching hospital in Punjab. We reviewed the medical records of all pregnant patients who were admitted to our department with PPROM on the basis of clinical and/or laboratory data from January 2014 through December 2014. Case group $1(n=75)$ included pregnant females admitted in the labour room with diagnosis of PPROM based on history and vaginal examination. Control group $2(n=75)$ included antenatal women admitted in labour room at 37 completed weeks of gestation or more with no history of PPROM and matched to case group with respect to age and parity. Case to control ratio was taken as $1: 1$. This is a secondary analysis of our study published before. ${ }^{11}$

Preterm Prelabour rupture of membranes is a syndrome characterized by rupture of membranes before 37 weeks of gestation and before onset of labour. Diagnosis of PPROM was based on history and vaginal examination. A history of sudden discharge of amniotic fluid from the vagina or feeling wet with a pooling of amniotic fluid in the posterior fornix on sterile speculum examination or a positive litmus paper test. A detailed history, general physical systemic and obstetric examinations were done in all women. Samples of high vaginal swabs (HVS) were taken from posterior fornix of vagina under direct vision using Cusco/Sims speculum and were studied for gram stain characteristics and culture-sensitivity by standard methods. Mid-stream urine sample was sent for cytology and culture-sensitivity. The urine samples were immediately sent to the Microbiology Department of the hospital taking all aseptic precautions and were inoculated on blood agar and MacConkey's agar using semi-quantitative method of inoculation. The culture plates were incubated at $370 \mathrm{C}$ for duration of 24 to 48 hours. Isolates were identified by standard methods.

The patients were managed conservatively in the obstetrical ward and monitored for signs of chorioamnionitis or fetal compromise. All patients received steroids for fetal lung maturity at gestational ages of less than 34 weeks. Reports of the urine and high vaginal swab cultures were collected and recorded. Antibiotic therapy was started or changed according to the sensitivity reports.

A multivariate analysis was used to find the association between PPROM and genitourinary infections. Microsoft Excel (Microsoft, Redmond, Washington, USA) and the Statistical Package for the Social Sciences (SPSS), Version 21 (IBM, Inc, Chicago, Illinois, USA) were used for data analysis. A P value of $<0.05$ was determined to be statistically significant.

\section{RESULTS}

This retrospective study was done on 150 pregnant women, divided into case group 1 and control group 2, matched for age and parity with 75 women in each group. During the study period, there were 1528 deliveries in the hospital and 75 cases of PPROM were diagnosed giving an overall incidence of $4.9 \%$. Baseline characteristics of the study population are shown in Table 1.Women in both the groups was in the range of 18-40 years. PPROM was more commonly seen in younger age group 21-25 yrs (44\%). The maximum number of women in the case group were primigravida $(45.33 \%)$ followed by second gravida $(30.67 \%)$. Table 1 shows that $70.6 \%(53 / 75)$ of women in the case group were unbooked, which was significantly more ( $\mathrm{p}$ 0.0001) than those in control group 2, i.e., $41.3 \%(31 / 75)$. According to modified 
Kuppuswamy socioeconomic scale, the two groups were comparable ( $p$ 0.93) for living standards. Fifty five women in group 1 belonged to urban population compared to 30 women in group 2, which was statistically significant (p 0.00002).

Table 1: Demographic data.

\begin{tabular}{|c|c|c|c|c|c|}
\hline & Case & Control & $x^{2}$ & p value & \\
\hline \multirow[t]{2}{*}{ Antenatal visits } & Booked & 22 & 44 & 13.3 & 0.0001 \\
\hline & Unbooked & 53 & 31 & & \\
\hline \multirow{5}{*}{$\begin{array}{l}\text { Modified Kuppuswamy SE } \\
\text { scale status }\end{array}$} & Upper & 10 & 8 & 3.626 & 0.4590 \\
\hline & Upper middle & 18 & 10 & & \\
\hline & Lower middle & 12 & 13 & & \\
\hline & Upper lower & 15 & 20 & & \\
\hline & Lower & 20 & 24 & & \\
\hline \multirow[t]{4}{*}{ BMI } & Normal & 25 & 24 & 1.882 & 0.5973 \\
\hline & Obese & 17 & 20 & & \\
\hline & Overweight & 25 & 19 & & \\
\hline & Underweight & 8 & 12 & & \\
\hline \multirow[t]{2}{*}{ Residence } & Urban & 55 & 30 & 16.97 & 0.00002 \\
\hline & Rural & 20 & 45 & & \\
\hline
\end{tabular}

Table 2: Overall presence of genitourinary infections.

\begin{tabular}{lllllll|} 
& & Case $(n=75)$ & Control $(n=75)$ & $\mathbb{X}^{2}$ & p-value & OR (95\% CI $)$ \\
\cline { 2 - 5 } Genitourinary infections & Present & $16(21.3 \%)$ & $7(9.3 \%)$ & \multirow{2}{*}{4.16} & 0.02252 & $2.618(1.021-7.239)$ \\
\cline { 2 - 7 } & Absent & $59(78.7 \%)$ & $68(90.7 \%)$ & & & \\
\hline
\end{tabular}

In our study, Table 2 shows that genitourinary infections were seen in 16 women in Case Group 1 (21.3\%), compared to 7 women in Control Group (9.3\%), the difference was statistically significant (p 0.02). Genitourinary infections is significantly associated with PPROM (OR, 2.618; 95\% CI, 1.021-7.239).The odds of developing PPROM was 2.6 times greater in women with genitourinary infections.

Table 3: Details of genitourinary infections.

\begin{tabular}{|c|c|c|c|c|}
\hline & \multicolumn{3}{|c|}{ Presence of infection } & \multirow{2}{*}{$\begin{array}{c}\mathbf{X}^{2} \\
\mathbf{p}-\text {-value }\end{array}$} \\
\hline & $\begin{array}{l}\text { Urine } \\
+\end{array}$ & $\begin{array}{l}\text { HVS } \\
+\end{array}$ & None & \\
\hline $\begin{array}{l}\text { Case } \\
(\mathrm{n}=75)\end{array}$ & $\begin{array}{l}06 \\
(8.1 \%)\end{array}$ & $\begin{array}{l}10 \\
(13.5 \%)\end{array}$ & $\begin{array}{l}59 \\
(78.7 \%)\end{array}$ & \multirow{2}{*}{$\begin{array}{ll}8.001 & 0.0183\end{array}$} \\
\hline $\begin{array}{l}\text { Control } \\
(n=75)\end{array}$ & $\begin{array}{l}06 \\
(8.1 \%)\end{array}$ & $\begin{array}{l}01 \\
(1.3 \%)\end{array}$ & $\begin{array}{l}68 \\
(90.7 \%)\end{array}$ & \\
\hline
\end{tabular}

It was observed in our study that genital infections were more commonly present in cases $(13.5 \%)$ than urinary infections $(8.1 \%)$ and this difference was statistically significant ( $\mathrm{p} 0.018$ ) as shown in table 3 .

E.Coli was the commonest microorganism cultured in urine and HVS cultures in both the groups. Microorganisms cultured and antibiotics used according to sensitivity are depicted in table 4 and 5 .

\section{DISCUSSION}

PPROM complicates only $3 \%$ of pregnancies but is associated with $40 \%$ of preterm deliveries ${ }^{2}$ and can result in significant neonatal morbidity and mortality. The overall incidence of PPROM (4.9\%) in our study is similar to that by Gunn et al. ${ }^{12}$

PPROM was more commonly seen in younger age group 21-25 yrs (44\%) in our study. The maximum number of women in the case group were primigravida $(45.33 \%)$ followed by second gravida $(30.67 \%)$. Most of these patients were of low socioeconomic group (62.7\%). These observations are consistent with studies by Faksh A et al and Joelle $\mathrm{M}$ et al. ${ }^{13,14}$

There are evidences demonstrating an association between ascending infection from the lower genital tract and PPROM. In patients with PPROM, about one-third of pregnancies have positive amniotic fluid cultures and studies have shown that bacteria have the ability to cross intact membranes. ${ }^{15-18}$ Infection is twice as frequent in PPROM as in preterm labour with intact membranes. The rates of positive cultures are higher in women who have PPROM (approximately 32.4\%) than in those with preterm labour and intact membranes (approximately $12.8 \%)^{19}$ 
Infection preceding PPROM is often subclinical and thought to ascend from the lower genitourinary tract. Following rupture of the membranes, ascending bacterial invasion can lead to intrauterine infections in up to $60 \%$ of cases in the absence of antibacterial therapy. ${ }^{9}$ Women with intrauterine infection deliver earlier than noninfected women and infants born with sepsis have mortality four times higher than those without sepsis. In addition, there are maternal risks associated with chorioamnionitis. $^{8}$

Table 4: Microorganisms isolated on urine culture and their respective sensitive antibiotics.

\begin{tabular}{|c|c|c|c|}
\hline \multicolumn{2}{|l|}{ Cases } & \multicolumn{2}{|c|}{ Controls } \\
\hline Microorganism & Antibiotic & Microorganism & Antibiotic \\
\hline $\mathrm{N}=6$ & & $\mathrm{~N}=6$ & \\
\hline $\begin{array}{l}\text { E.Coli- } \\
2(33.3 \%)\end{array}$ & $\begin{array}{l}\text { Nitrofurantoin } \\
\text { Cephalexin } \\
\text { Piperacillin+Tazobactum }\end{array}$ & E.Coli-2 (33.3\%) & $\begin{array}{l}\text { Nitrofurantoin } \\
\text { Cephalexin } \\
\text { Piperacillin+ Tazobactum }\end{array}$ \\
\hline $\begin{array}{l}\text { Proteus vulgaris- } \\
2(33.3 \%)\end{array}$ & $\begin{array}{l}\text { Chloramphenicol } \\
\text { Gentamycin } \\
\text { Piperacillin+Tazobactum }\end{array}$ & $\begin{array}{l}\text { Proteus vulgaris- } \\
2(33.3 \%)\end{array}$ & $\begin{array}{l}\text { Chloramphenicol } \\
\text { Gentamycin } \\
\text { Piperacillin+ Tazobactum }\end{array}$ \\
\hline $\begin{array}{l}\text { Enterococcus fecalis- } \\
1(16.66 \%)\end{array}$ & $\begin{array}{l}\text { Ampicillin } \\
\text { Ciprofloxacin } \\
\text { Vancomycin }\end{array}$ & $\begin{array}{l}\text { Enterococcus } \\
\text { fecalis- } \\
1(16.66 \%)\end{array}$ & $\begin{array}{l}\text { Ampicillin } \\
\text { Ciprofloxacin } \\
\text { Vancomycin }\end{array}$ \\
\hline $\begin{array}{l}\text { Staphyloccus aureus } \\
\text { (MSSA) - } 1 \\
(16.66 \%)\end{array}$ & Amoxycillin +clauvulinic acid & $\begin{array}{l}\text { Klebsiella- } \\
1(16.66 \%)\end{array}$ & $\begin{array}{l}\text { Chloramphenicol } \\
\text { Gentamycin } \\
\text { Cefoxitin }\end{array}$ \\
\hline
\end{tabular}

Table 5: Microorganisms isolated on HVS culture and their respective sensitive antibiotics.

\begin{tabular}{|llll|}
\hline \multicolumn{1}{|c|}{ Cases } & \multicolumn{1}{c|}{ Controls } \\
\hline Microorganism & Antibiotic & Microorganism & Antibiotic \\
\hline $\begin{array}{l}\text { E.coli- } \\
4(40 \%)\end{array}$ & $\begin{array}{l}\text { Cefoperazone+sulbactum } \\
\text { Nitrofurantoin } \\
\text { Cephalexin }\end{array}$ & $\begin{array}{l}\text { Candida albicans- } \\
\text { Piperacillin+ Tazobactum }\end{array}$ & $\begin{array}{l}\text { Fluconazole } \\
\text { Itraconazole }\end{array}$ \\
\hline $\begin{array}{l}\text { Proteus vulgaris- } \\
2(20 \%)\end{array}$ & Piperacillin+ Tazobactum & & \\
\hline $\begin{array}{l}\text { Enterococcus fecalis- } \\
1(10 \%)\end{array}$ & Linezolid & & \\
\hline $\begin{array}{l}\text { Candida albicans- } \\
1(10 \%)\end{array}$ & Fluconazole & Itraconazole & \\
\hline $\begin{array}{l}\text { Pseudomonas } \\
\text { aeruginosa- } \\
1(10 \%)\end{array}$ & Amphotericin B & & \\
\hline $\begin{array}{l}\text { Staphyloccus aureus( } \\
\text { MRSA)- } \\
1(10 \%)\end{array}$ & Vephalexin & & \\
\hline
\end{tabular}

Infection preceding PPROM is often subclinical and thought to ascend from the lower genitourinary tract. Following rupture of the membranes, ascending bacterial invasion can lead to intrauterine infections in up to $60 \%$ of cases in the absence of antibacterial therapy. 9 Women with intrauterine infection deliver earlier than noninfected women and infants born with sepsis have mortality four times higher than those without sepsis. In addition, there are maternal risks associated with chorioamnionitis. $^{8}$ 
Incidence of genitourinary infections in our study was $21.3 \%$ which is comparable to study by Romero et al. ${ }^{20}$ In our study, positive high vaginal swab cultures were noted in $13.5 \%(10 / 75)$ in case group and $1.3 \%(1 / 75)$ in control group which was similar to results of $\mathrm{Li} \mathrm{N}$ et al. ${ }^{21}$ Lajos et al have reported the prevalence of endocervical colonization to be $14.20 \%$ in preterm labour or preterm prelabour rupture of membranes. ${ }^{22}$ E.Coli was the commonest microorganism cultured in urine and HVS cultures in both the groups in our study which was similar to a study conducted in Lahore by Asindi AA et al. ${ }^{23}$

Management of PPROM varies according to the gestational age of the fetus. Expectant management and immediate delivery are two potential options of management in patients with PPROM with its advantages and disadvantages. The management of pregnancies complicated with PPROM, is individualized, highly controversial and challenging. Administration of adjunctive prophylactic antibiotics is one of the interventions known to improve obstetric outcome. The goal of antibiotic therapy is to reduce the frequency of maternal and fetal infection and delay the onset of preterm labour (i.e., prolong the latency period).

Limitations of this study were the retrospective nature of the study. A second limitation was the relatively small amount of sample size. To fully assess the effect of genitourinary infections as a risk factor for PPROM, a larger group may be favorable. Hence the findings of this study may not reflect the true situation in the general population and should be interpreted with caution.

\section{CONCLUSIONS}

Genitourinary infections contribute significantly to the preventable causes of PPROM. On the basis of our study it can be recommended that women coming for first antenatal checkup should be screened for the presence of asymptomatic genitourinary infections. Vigilance in early recognition of genitourinary infections in pregnancy with or without PPROM and prompt treatment is the key for successful management in order to optimize the maternal and fetal outcome.

Funding: No funding sources

Conflict of interest: None declared

Ethical approval: The study was approved by the Institutional Ethics Committee

\section{REFERENCES}

1. Charles B. Obstetrics and Gynecology, 7e. Philadelphia: Wolters Kluwer Health/Lippincott Williams \& Wilkins. pp. Chapter 17: Premature Rupture of Membranes. 2014:169-73.

2. Meis PJ, Ernest JM, Moore ML. Causes of low birth weight births in public and private patients. Am J Obstet Gynecol. 1987;156:1165-8.
3. Lonky NM, Hayashi RH: A proposed mechanism for pre mature rupture of the membranes. Obstet Gynecol Surv. 1988;43:22.

4. Naeye RL. Factors that predispose to premature rupture of the fetal membranes. Obstet Gynecol. 1982;60:93.

5. Gibbs RS, Blanco JD. Premature rupture of the membranes. Obstet Gynecol. 1982;60:671.

6. Bendon RW, Faye-Petersen O, Pavlova Z, Qureshi F, Mercer B, Miodovnik M, et al. Fetal membrane histology in preterm premature rupture of membranes: comparison to controls, and between antibiotic and placebo treatment. Pediatr Dev Pathol. 1999;2:552-8.

7. Goldenberg RL, Hauth JC, Andrews WW. Intrauterine infection and preterm delivery. $\mathrm{N}$ Engl $\mathrm{J}$ Med. 2000;342:1500-7.

8. Klein LL, Gibbs RS. Use of microbial cultures and antibiotics in the prevention of infection-associated preterm birth. Am J Obstet Gynecol. 2004;190:1493502.

9. Mercer BM, Arheart KL. Antimicrobial therapy in expectant management of preterm premature rupture of the membranes. Lancet. 1995; 346:1271-9.

10. Riyami NA,Shezawi FA, Al-Ruheli,Al-Dughaishi T, Al-Khabori M. Perinatal Outcome in Pregnancies with Extreme Preterm Premature Rupture of Memranes (Midtrimester PROM). Sultan Qaboos Univ Med J. 2013;13(1):51-6.

11. D'souza AS, Walia M, Gupta G, Samuel CJ, Francis SK, Goyal S. Feto-maternal outcome in pregnancies with preterm premature rupture of membranes: a tertiary hospital experience. Int J Reprod Contracept Obstet Gynecol. 2015;4(5):1529-33.

12. Gunn GL, Mishell DR, Morton DG. Incidence of PROM. Am J Obstet Gynaecol. 1970;106:469.

13. Faksh A, Wax JR, Lucas FL, Cartin A, Pinette MG. Preterm premature rupture of membrane $>32$ weeks gestation: impact of revised practice guidelines. Am J Obstet Gynecol. 2011; 205: 340 e1-e5.

14. Lieman, J.M., Brumfield, C.G., Carlo, W., Ramsey, P.S. Preterm premature rupture of membranes: is there an optimal gestational age for delivery? Obstet Gynecol. 2005;105:12-7.

15. Carroll SG, Sebire NJ, Nicolaides KH. Preterm prelabour amniorrhexis. NewYork/London: Parthenon, 1996.

16. Broekhuizen FF,Gilman M,Hamilton PR. Amniocentesis for gram stain and culture in preterm premature rupture of the membranes. Obstet Gynecol. 1985;66:316-21.

17. Galask RP, Varner MW, Petzold CR,Wilbur SL.Bacterial attachment to the chorionic membranes. Am J Obstet Gynecol. 1984;148:915-28.

18. Gyr TN, Malek A, Mathez-Loic F, Altermatt HJ, Bodmer T, Nicolaides K, et al. Permeation of human chorioamniotic membranes by Escherichia coli in vitro.Am J Obset Gynecol. 1994;170:223-7. 
19. Goncalves LF, Chaiworapongsa T, Romero R. Intrauterine infection and prematurity. Ment Retard Dev Disabil Res Rev. 2002;8:3-13.

20. Romero R, Mazor M, Avila C. Prevalence, microbiology and clinical significance of microbial invasion of the cavity in term premature rupture of the membranes. SPO Abstract 213. Am J Obstet Gynaecol. 1991;164:305.

21. Li N, Fu Q, Cai W. Cause analysis and clinical management and experience of the premature rupture of the membrane. Open $\mathrm{J}$ obstet gynaecol. 2013;3:22-6.

22. Lajos GJ, Junior RP, Nomura ML, et al. Cervical bacterial colonization in pregnant women with preterm labour or premature rupture of membranes. Rev Bras Gynecol Obstet. 2008;30(8):393-9.

23. Asindi AA, Archibong El, Mannan NB. Motherinfant colonization and neonatal sepsis in prelabour rupture of membranes. Saudi Med J. 2002;23:12704.

Cite this article as: D'souza AS, Gupta G, Mahindru D, Walia M, Katumalla FS, Goyal S. Genitourinary infections as a risk factor for preterm prelabour rupture of membranes: a hospital based case control study. Int J Reprod Contracept Obstet Gynecol 2015;4:1686-91. 